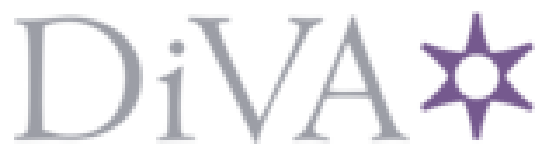

http://www.diva-portal.org

This is the published version of a paper published in .

Citation for the original published paper (version of record):

Condo, A F., Allertz, C., Sichen, D. (2017)

Experimental Determination of Sulphide Capacities of Blast Furnace Slags with Higher MgO Contents.

IRONMAKING \& STEELMAKING

https://doi.org/10.108o/o3019233.2017.1366089

Access to the published version may require subscription.

N.B. When citing this work, cite the original published paper.

Permanent link to this version:

http://urn.kb.se/resolve?urn=urn:nbn:se:kth:diva-228339 


\title{
Experimental determination of sulphide capacities of blast furnace slags with higher MgO contents
}

\author{
Adolfo Firmino Timóteo Condo ${ }^{\mathrm{a}, \mathrm{b}}$, Carl Allertz $^{\mathrm{c}}$ and Du Sichen ${ }^{\mathrm{a}}$ \\ ${ }^{a}$ Department of Materials Science and Engineering, Royal Institute of Technology, Stockholm, Sweden; ${ }^{b}$ Faculty of Engineering, Eduardo Mondlane \\ University, Maputo, Moçambique; ' Elkem AS, Kristiansand, Norway
}

\section{ABSTRACT}

Sulphide capacity measurements of slag with $\mathrm{MgO}$ content up to 18 mass\% were carried out at 1713 1743 and $1773 \mathrm{~K}$ to obtain reliable data for the blast furnace process. In the measurement, the slag is equilibrated with copper at a controlled oxygen partial pressure for $24 \mathrm{~h}$. The sulphide capacities are calculated based on the sulphur analyses for both slag and copper.

\section{ARTICLE HISTORY}

Received 20 April 2017

Accepted 24 July 2017

\section{KEYWORDS}

Sulphide capacity; blast furnace slag; experimental slag-metal equilibrium
The increasing demand on improvement of steel cleanness and process optimisation has drawn a great attention on the desulphurisation of hot metal before the BOF process [1-15]. If the capacity of the blast furnace slag to capture sulphur can be optimally utilised, it would have a big impact on the process optimisation and material saving $[5,6,8]$. Despite of the tremendous effort and a huge number of publications, there are still only a few data of sulphide capacity for the $\mathrm{CaO}-\mathrm{SiO}_{2}-\mathrm{Al}_{2} \mathrm{O}_{3}-\mathrm{MgO}$ slag system with magnesia content above 15 mass\%. In the modern steel plants, the slag composition varies with the blast furnace. In some of the furnaces, slags containing higher $\mathrm{MgO}$ contents are used. For instance, the blast furnaces at Oxelösund-SSAB use slag having higher $\mathrm{MgO}$ contents ranging from 14 to 18 mass\%. To optimise the blast furnace process, the sulphide capacity data for slags are essential. The main objective of this work is to determining the sulphide capacities of the blast furnace slags with $\mathrm{MgO}$ contents up to 18 mass $\%$.

The details of the experimental setup can be found in previous publications $[2,16]$. As shown in Figure 1, a high temperature furnace with graphite heating element was employed. The $\mathrm{Al}_{2} \mathrm{O}_{3}$ reaction tube was internally connected to a water-cooled quenching chamber. 1-3 Mo crucibles containing the samples were kept in the Mo crucible holder that was connected to a lifting system using a Mo rod. It took less than $2 \mathrm{~s}$ to lift the sample from hot zone to the quenching chamber for quenching.

In a typical run, copper powder (purity $>99.8 \%$ ) was well mixed with $\mathrm{Cu}_{2} \mathrm{~S}(99.5 \%)$ and placed in a Mo crucible. Thereafter, the slag components were well mixed and put on the top of the cooper layer in the molybdenum working crucible (18 mm, IH: $49 \mathrm{~mm}$ ). After positioning the samples in the even temperature zone of the furnace, the whole system was completely sealed using O-rings. The reaction chamber was evacuated for $30 \mathrm{~min}$ and then refilled with the reaction gas. Different mixtures of $\mathrm{CO}-\mathrm{CO}_{2}$ were used to set the partial pressures of oxygen at three different temperatures. To ensure that the equilibrium would be attained, samples were kept at respective temperature for $24 \mathrm{~h}$ [16]. The samples were quenched when the equilibration time was reached. The quenching was done by fast moving of the assembly to the quenching chamber and at the same time blowing argon with high flow rate on the samples. The analyses of sulphur contents in the copper and slag were made by combustion method using a LECO CS-600 analyser. The samples along with their containers were weighed before and after the experiments. No appreciable weight loss was noticed indicating thereby that the mass exchange between the sample and gas phase was negligible. The results of the XRF analysis confirmed that the fractions of the weighed-in oxides were maintained throughout the equilibrating time.

A mixture of $98.1 \% \mathrm{CO}-1.9 \% \mathrm{CO}_{2}$ was used for the experiment at $1713 \mathrm{~K}$ to generate an oxygen partial pressure of $2.16 \times 10^{-12} \mathrm{~atm}$, a gas mixture of $98.7 \% \mathrm{CO}-1.3 \% \mathrm{CO}_{2}$ at $1743 \mathrm{~K}$ to generate an oxygen partial pressure of $1.97 \times 10^{-12} \mathrm{~atm}$ and a gas mixture of $99.0 \% \mathrm{CO}-1.0 \% \mathrm{CO}_{2}$ to generate an oxygen partial pressure of $2.23 \times 10^{-12} \mathrm{~atm}$ at $1773 \mathrm{~K}$. All the slag compositions are chosen within the homogeneous liquid region according to phase diagram of the $\mathrm{CaO}-\mathrm{SiO}_{2}-\mathrm{MgO}-\mathrm{Al}_{2} \mathrm{O}_{3}$ system $[17,18]$. It is worthwhile to mention that all the samples were glassy after quenching, indicating that the samples were liquid during the experiments. The experimental results are shown in Table 1. To examine the reliability of the experiments, some experiments were repeated. As shown in Table 1, the agreements between the results of the two runs for different pairs of samples, for example, SC7 and SC7*, SC8 and SC8*, SC9 and SC9* and so on are excellent

Richardson and Frincham [1] defined the sulphide capacity as

$$
C_{\mathrm{S}}=\frac{K \times a_{\mathrm{O}^{2-}}}{f_{\mathrm{S}^{2-}}}=\left(\operatorname{mass} \% \mathrm{~S}^{2-}\right) \times \sqrt{\frac{p_{\mathrm{O}_{2}}}{p_{\mathrm{S}_{2}}}}
$$

where $K$ stands for equilibrium constant, $f_{\mathrm{s}^{2-}}$ is the activity coefficient of sulphur ions in the slag, $a_{\mathrm{O}^{2-}}$ is the activity of oxygen ions in the slag, $p_{\mathrm{O}_{2}}$ and $p_{\mathrm{S}_{2}}$ are the partial pressures of oxygen and sulphur, and (mass $\% \mathrm{~S}^{2-}$ ) is the concentration of sulphide 


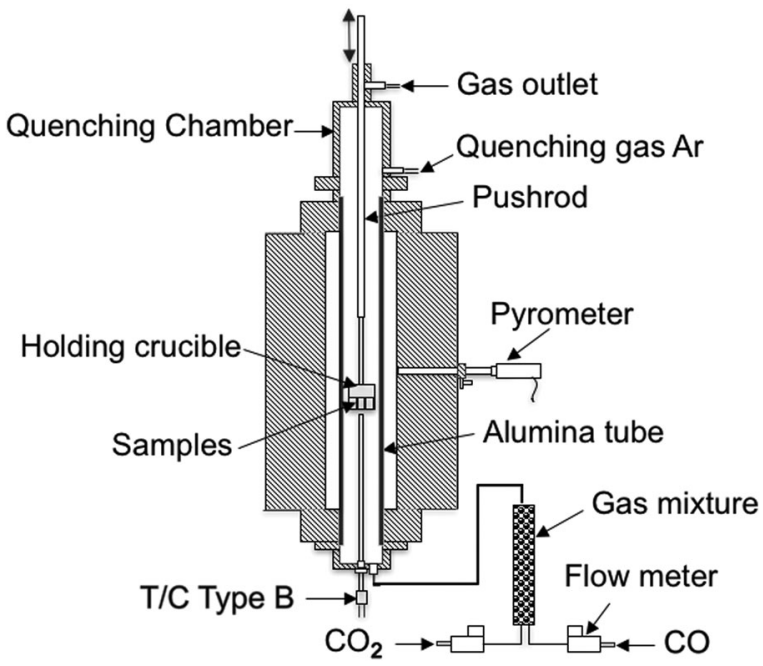

Figure 1. Scheme of the experimental setup.

ions in the slag. Using Equation (1), the sulphide capacity can be calculated by the concentration of sulphur in the slag knowing the partial pressure of oxygen and sulphur. While the oxygen partial pressure is controlled by the $\mathrm{CO}-\mathrm{CO}_{2}$ gas mixture, the sulphur partial pressure can be evaluated using the activity of sulphur in copper based on reaction (2) using the literature data $[19,20]$ :

$$
\frac{1}{2} S_{2 \text { (gas) }}=\underline{S}_{\mathrm{Cu}}
$$

The calculated $C_{S}$ values of the slags are included in Table 1. In order to compare the present values with the literature data, the sulphide capacities obtained in the present study are plotted in Figures 2 and 3 along with the literature data $[3,7,9,11,15]$ at 1773 K. Nzotta et al. [3], Kärsrud [7], Kalyanram et al. [9], Seo and Kim [11] and $\mathrm{Ma}$ et al. [15] have measured the sulphide capacities of the $\mathrm{CaO}-\mathrm{SiO}_{2}-\mathrm{MgO}-\mathrm{Al}_{2} \mathrm{O}_{3}$ system with compositions close to the blast furnace slags at $1773 \mathrm{~K}$. For the comparison, the experimental points having alumina contents differing less than 2 mass $\%$ from either 10 or 15 mass $\%$ are plotted in the two figures. Figures 2 and 3 show that the present results are in good agreement with the data reported by Kärsrud [7], and Kalyanram et al. [9], and reasonable agreement with the data from Seo and Kim [11] and Ma et al. [15] On the other hand, the data by Nzotta et al. [3] appear to be somewhat lower.

In accordance with the data of Kalyanram et al. [9], the present results show that the desulphurisation power of the slag will be far more affected by silica than that by alumina. A comparison of Figure 2 and Figure 3 reveals that an increase of $\mathrm{Al}_{2} \mathrm{O}_{3}$ from 10 to 15 mass $\%$ has minor effect on $C_{\mathrm{s}}$, with $C_{\mathrm{s}}$ values being slightly lowered. On the other hand, both figures show an applicable decrease in sulphide capacity when the slag composition moves towards the $\mathrm{SiO}_{2}$ corner. The variation of $\mathrm{SiO}_{2}$ content from 40 to 35 mass\% led to a sharp increase of sulphide capacity in both figures.

The blast furnace slag in Oxelösund-SSAB contains usually 14-15 mass $\% \mathrm{Al}_{2} \mathrm{O}_{3}$ and 32-34 mass $\% \mathrm{SiO}_{2}$. As seen in Figure 2, at a constant $\mathrm{SiO}_{2}$ content (32-34 mass\%), the increase of

Table 1. Experimental results of sulphide capacity in $\mathrm{CaO}-\mathrm{SiO}_{2}-\mathrm{MgO}-\mathrm{Al}_{2} \mathrm{O}_{3}$ slag system having 10 and 15 mass $\% \mathrm{Al}_{2} \mathrm{O}_{3}$.

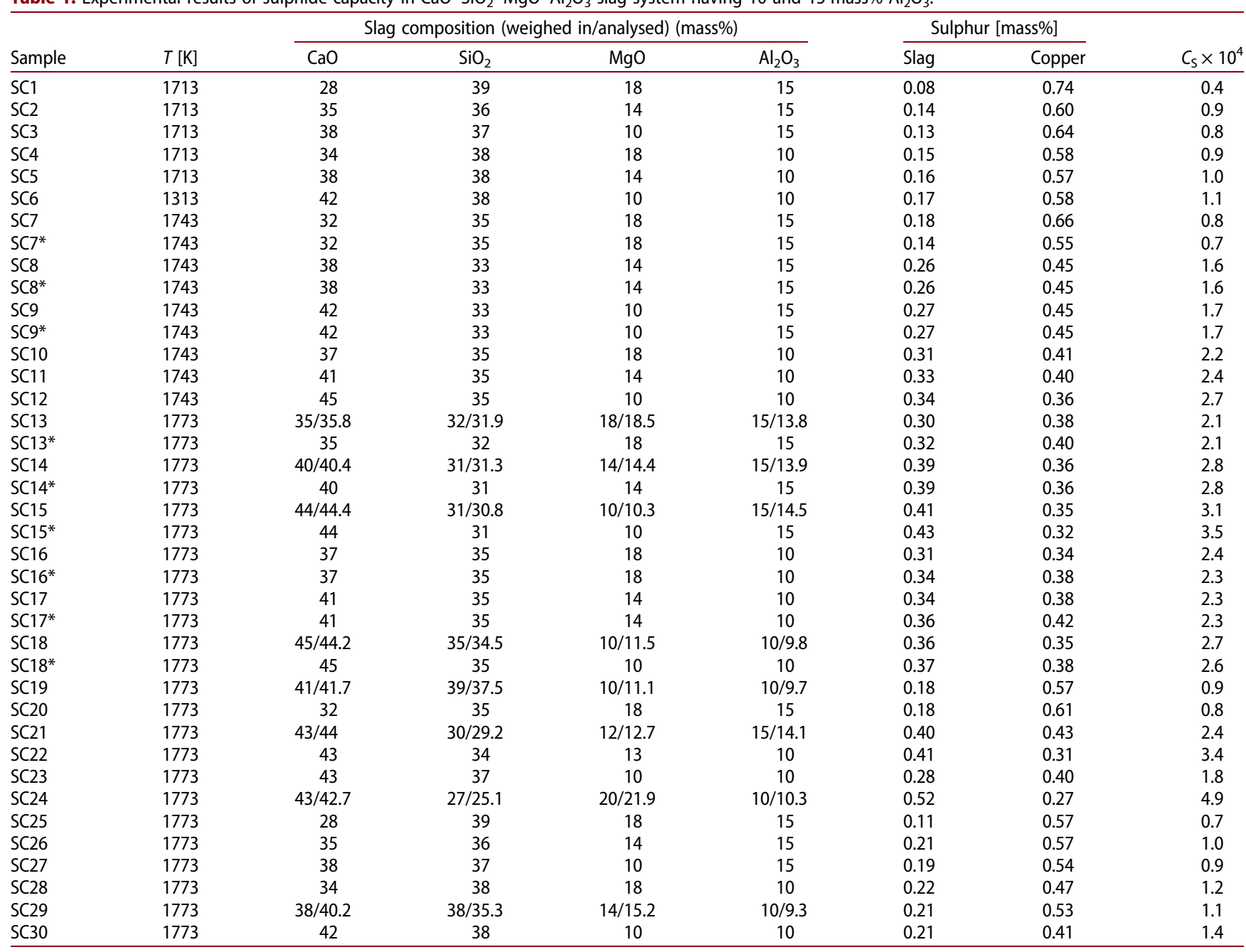




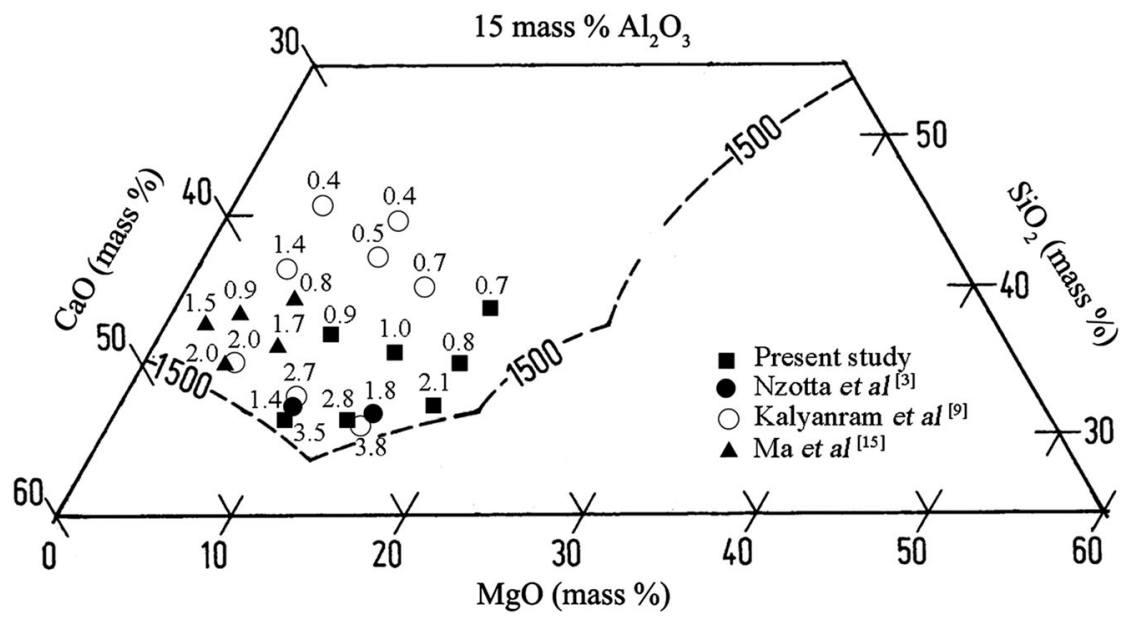

Figure 2. Experimental and literature $\mathrm{C}_{\mathrm{S}} \times 10^{4}$ data in the $\mathrm{CaO}-\mathrm{SiO}_{2}-\mathrm{MgO}-\mathrm{Al}_{2} \mathrm{O}_{3}(15$ mass\%) system at $1773 \mathrm{~K}$.

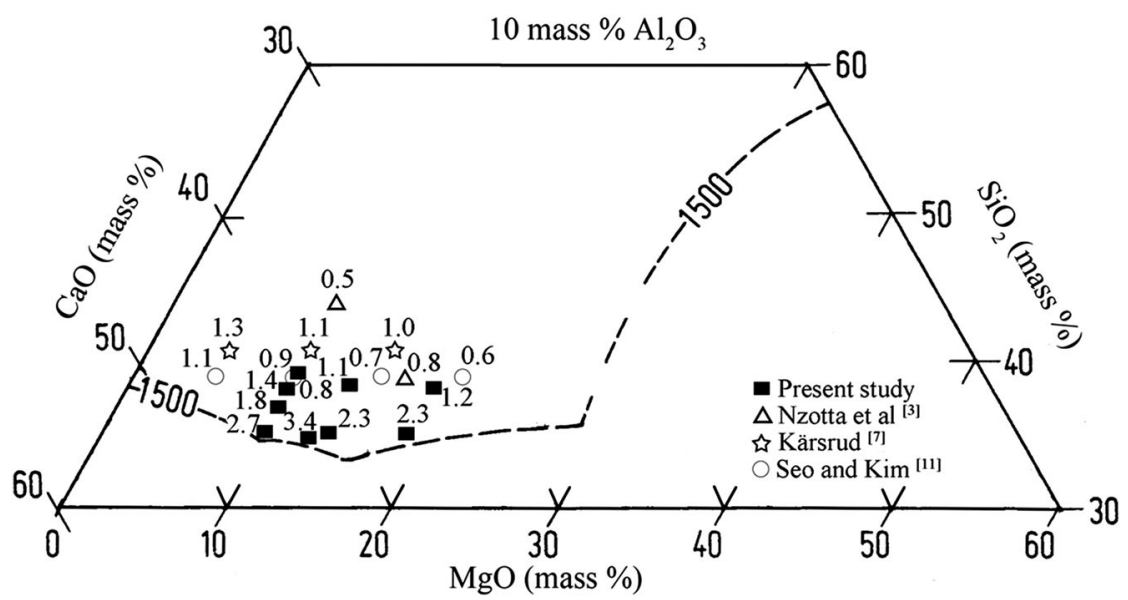

Figure 3. Experimental and literature $\mathrm{C}_{\mathrm{S}} \times 10^{4}$ data in the $\mathrm{CaO}-\mathrm{SiO}_{2}-\mathrm{MgO}-\mathrm{Al}_{2} \mathrm{O}_{3}(10$ mass\%) system at $1773 \mathrm{~K}$.

$\mathrm{MgO}$ content above 14 mass\% in the slag decreases the sulphide capacity. This observation shows clearly that slags with high magnesia content (>14 mass\%) will be less efficient for sulphur removal inside the blast furnace in the case of usually used alumina and silica ranges. Hence, in the blast furnace operation, it is desired to keep the MgO lower than 14 mass\%. Note that other parameters, e.g. the flux in the iron ore pellets, should also be taken into consideration when making the process optimisation.

\section{Disclosure statement}

No potential conflict of interest was reported by the authors.

\section{Funding}

The authors would like to thank the Swedish International Development Agency (SIDA) for financial support of this study.

\section{References}

[1] Richardson FD, Frincham CJB. Sulphur in silicate and aluminate slags. J Iron Steel Inst. 1954;178:4-15.

[2] Condo AFT, Lindström D, Sichen D. Study on the effect of aging on the ability of calcium carbide for hot metal desulfurization. Steel Res. 2016;87:1137-1143.

[3] Nzotta MM, Sichen D, Seetharaman S. Sulphide capacities in some multi component slag systems. ISIJ Int. 1998;38:1770-1779.
[4] Condo AFT, Lindström D, Kojola N, et al. Study on the equilibrium of slag and hot metal at tapping with respect to sulfur. Steel Res. 2016;87:1-9.

[5] Osborn EF, De Vries RC, Gee KH, et al. Optimum composition of blast furnace slag as deduced from liquidus data for the quaternary system CaO-MgO- $\mathrm{Al}_{2} \mathrm{O}_{3}-\mathrm{SiO}_{2}$. J Metals. 1954;200:33-45.

[6] McCaffery R, and Co-workers. Research on blast furnace slags. Trans AIME. 1932;100:64-85.

[7] Kärsrud K. Sulphide capacities of synthetic blast furnace slags at $1500^{\circ} \mathrm{C}$. Scand J Metall. 1984;13:144-150.

[8] Holbrook WF, Joseph TL. Relative desulfurizing powers of blastfurnace slags. Trans AIME. 1936;120:99-117.

[9] Kalyanram MR, Macfarlane TG, Bell HB. The activity of calcium oxide in slags in the systems $\mathrm{CaO}-\mathrm{MgO}-\mathrm{SiO}_{2}, \mathrm{CaO}-\mathrm{Al}_{2} \mathrm{O}_{3}-\mathrm{SiO}_{2}$, and $\mathrm{CaO}-\mathrm{MgO}-\mathrm{Al}_{2} \mathrm{O}_{3}-\mathrm{SiO}_{2}$ at $1500^{\circ} \mathrm{C}$. J Iron Steel Inst. 1960;195: 58-64.

[10] Abraham KP, Richardson FD. Sulphide capacities of silicate melts PART II. Iron Steel Res. 1960;196:313-317.

[11] Seo JD, Kim SH., et al. The sulphide capacity of $\mathrm{CaO}-\mathrm{SiO}_{2}-\mathrm{Al}_{2} \mathrm{O}_{3}-\mathrm{MgO}$ (-FeO) smelting reduction slags. Steel Res. 1999;70:203-208.

[12] Shi CB, Yang XM, Jiao JS, et al. A sulphide capacity prediction model of $\mathrm{CaO}-\mathrm{SiO}_{2}-\mathrm{MgO}-\mathrm{Al}_{2} \mathrm{O}_{3}$ ironmaking slags based on the lon and molecule coexistence theory. ISIJ Int. 2010;50:1362-1372.

[13] Hayakawa $H$, Hasegawa $M$, Nuki KO, et al. Sulphide capacities of $\mathrm{CaO}-\mathrm{SiO}_{2}-\mathrm{Al}_{2} \mathrm{O}_{3}-\mathrm{MgO}$ Slags. Steel Res. 2006;77:14-20.

[14] Xin T, Chushao X., et al. Sulphur distribution between $\mathrm{CaO}-\mathrm{SiO}_{2}-\mathrm{TiO}_{2}$ $\mathrm{Al}_{2} \mathrm{O}_{3}-\mathrm{MgO}$ slag and carbon-saturated iron at $1773 \mathrm{~K}$. ISIJ Int 1995;35:367-371.

[15] $\mathrm{MaX}$, Shen $\mathrm{M}, \mathrm{Xu} \mathrm{H}$, et al. Sulphide capacity of $\mathrm{CaO}-\mathrm{SiO}_{2}-\mathrm{Al}_{2} \mathrm{O}_{3}-\mathrm{MgO}$ system relevant to Low MgO blast furnace slags. ISIJ Int. 2016. http:// dx.doi.org/10.2355/isijinternational.ISIJINT-2016-274. 
[16] Allertz C, Sichen D., et al. Sulfide capacity in ladle slag at steelmaking temperatures. Metall Trans B. 2015;46B:2609-2615.

[17] Verein Deutscher Eisenhüttenleute (VDEh). 2nd ed., SLAG ATLAS, Verlag Stahleisen GmbH, D-Düsseldorf; 1995, 157.

[18] $\mathrm{Ma} \mathrm{X}$, Wang G, Wu S, et al. Phase equilibria in the $\mathrm{CaO}-\mathrm{SiO}_{2}-\mathrm{Al}_{2} \mathrm{O}_{3}$ $\mathrm{MgO}$ system with $\mathrm{CaO} / \mathrm{SiO}_{2}$ ratio of 1.3 relevant to iron blast furnace slags. ISIJ Int. 2015. http://dx.doi.org/10.2355/isijinternational. ISIJINT-2015-263.

[19] Rao YK. Stoichiometry and thermodynamics of metallurgical processpart 2. New York (NY): Cambridge University Press; 2009, 883.

[20] Sigworth GK, Elliott JF., et al. The thermodynamics of dilute liquid copper alloys. Can Metall Q. 1974;13:455-461. 